\title{
How Important Risk Management Culture in Local Governments?
}

\author{
Resha Dwi Ayu Pangesti Mulyono \\ Accounting Departement, University of Jember, Indonesia \\ Corresponding Author: reshadwiayupm.feb@unej.ac.id
}

Article Info

\section{Keyword:}

Risk Management

Culture;

Local Government;

Good Governance;

\section{Kata Kunci:}

Budaya Manajemen Risiko;

Pemerintah Daerah;

Tata Kelola;

\begin{abstract}
The aim of this study is how important to develop risk management culture in Local Government. This research uses a case study approach with an exploratory study, then the steps taken by researcher to analyze interview data by: (a) informal conversation interviews, (b) approaches using interview general guidelines, and (c) open standard interviews. The results of the interviews were recorded with a recording aid and then processed with NVIVO software then analyzed and the conclusions drawn from the interviews. The Results of this research is the important thing from risk management culture in Local Government for Creating value, an integral part of organizational processes, part of decision making, and explicitly discussing uncertainty for Good Governance.
\end{abstract}

Abstrak: Tujuan dari penelitian ini adalah seberapa penting untuk mengembangkan budaya manajemen risiko di Pemerintah Daerah. Penelitian ini menggunakan pendekatan studi kasus dengan studi eksplorasi, kemudian langkah-langkah yang diambil oleh peneliti untuk menganalisis data wawancara dengan: (a) wawancara percakapan informal, (b) pendekatan menggunakan pedoman umum wawancara, dan (c) wawancara standar terbuka. Hasil wawancara direkam dengan alat perekam dan kemudian diproses dengan perangkat lunak NVIVO kemudian dianalisis dan kesimpulan diambil dari wawancara. Hasil penelitian ini adalah hal penting dari budaya manajemen risiko di Pemerintah Daerah untuk Menciptakan nilai, bagian integral dari proses organisasi, bagian dari pengambilan keputusan, dan secara eksplisit membahas ketidakpastian untuk tata kelola yang baik.

Article History: Received; 2020-01-22 Revised; 2020-02-20 Accepted; 2020-02-22

\section{INTRODUCTION}

Development of business today is very rapid both offline and online, the fact it can be happened in private sector or public sector. Business activity also increases every second according to the current demand and supply conditions. In such an event there must also be many risks. There is no business that is not at risk nowadays, the risk can occur anytime and anywhere. One aspect of the risk management landscape is the responsibility of organizations (especially financial institution) to develop a strong, accountable and proactive risk culture. Many practitioners stresses that it's easier to talk about meeting specific risk-management requirements than it is to talk about risk culture. Organizations are subject to a diverse set of formal risk-management requirements, including internal audit, compliance, contingency planning, enterprise risk management and other activities (Haviernikova, 2016). Risk management present not only in the private sector, in the public sector or the Government also experienced a significant change in activities. With this complexity problem, the risks faced will increase; therefore good governance practices are needed.

Business leaders and Government agencies must be able to clearly organize related risks to be faced later. Clarity in setting the risk management organization structure will facilitate the 
management of risk management in corporations or agencies. At present the Government agencies have focused on holding a clean and responsible government through improving public services. Public services are planned through work programs and activities and the budget has been prepared through a long process. All activities are outlined in short, medium and long term plans which must be in accordance with the budget. In relation to activities, a risk awareness culture must be instilled, the objective of the risk awareness culture is that each member of the organization is aware of risk, and makes certain decisions taking into account the risk aspects. Briefly Mamduh (2016) explains the purpose of risk-conscious culture is so that members are more careful in making decisions. If the member is aware of the risk, the organization (which consists of a group of individuals) will be more sensitive to risk. Risk awareness culture is also a concern for the Government to deal with risk-based audits and prevent fraud. Developing this behavior encourages layers of workers to be more careful and careful in dealing with problems that have the potential for every work activity.

One strategic aspect of concern in risk awareness culture is the management of regional finances which is currently important, because it forces local governments to ensure transparency, efficiency and strong accountability in the use of regional finances. This is needed, so that the principles of performance budget that are adopted in the preparation and implementation of the budget can be upheld, and thus the realization of government spending on development programs and priority activities, can provide optimal benefits for the benefit of the community. To be able to provide accurate information, all are determined through performance measurement measures on each program and activity. Determination of performance is used as a basis for evaluating the success / failure of achieving organizational goals and objectives, creating performance benchmarks as a basis for evaluating apparatus performance, and as a basis for rewards and sanctions.

According to Sheedy \& Griffin (2018) risk governance (emphasizing internal structures and risk culture) is a relatively new approach to the governance of financial institutions that is being widely adopted in the industry but nowadays risk governance is adopted in Government. Due to obvious assessment challenges, to date no evidence exists regarding the effectiveness of risk structures nor the status of risk culture in financial institutions. In Indonesia according to Government Regulation Number 60 of 2008 concerning the Government Internal Control System (SPIP) is an effort of the Government to fulfill article 58 of Law Number 1 of 2004 concerning the State Treasury, namely to implement a system of internal control in the Government as a whole in order to improve performance, transparency and accountability. With the application of effective internal control, it is expected to provide. Government Internal Control System (SPIP) has 5 (five) elements of control, namely: 1) Control environment, 2) Risk assessment, 3) Control activities, 4) Information and communication, and 5) Internal control monitoring. The best way to comprehend the risk culture across an organization is to engage directly with the employees whose daily activities are to identify, take and manage risk (Cortez, 2011). Manage risk for Government is important nowadays, it have impact to good governance, they are about delivering priorities, achieving objectives, behaving with integrity and acting in the public interest, and in ways that are consistent with legal, regulatory and Government policy obligations. Effective risk management supports good governance as it assists in determining priorities and setting objectives, in analyzing uncertainties within decision-making arrangements, in clarifying accountabilities and in demonstrating how the public interest is best served (Bird, 2018) .

According Tiwari (2017) local governments are required some means to improve their developments which one of them is an effective internal audit which should goes along with the set up objectives by councils, and also improve the performance of organizations. In other hand, the risk management incorporate the main role in effective internal audit so that the management can direct the resources more wisely and effectively. Risk management and internal audit must be utilized by the public and private sectors as same to reach sustainable development at local government. One of Local Government who implemented the risk management culture is Banyuwangi Government. From the top leader to bottom, Banyuwangi have commitment to be good and clean government. Create a good culture, taste, tolerance, governance and policy regulated in regent regulations. To make Banyuwangi Government that is 
appreciated for its desire to create the best change, one of which is to build awareness of risk culture management from the start.

The aim of this study is how important to develop risk management culture in Local Government. The research results will be used to make recommendations on how to create a risk management culture in the organizations as daily activities at all levels of operations. Building a risk management culture on all fronts will help improve government performance, be controlled and in accordance with the objective of being free from corruption in accordance with the KPK's direction.

\section{RESEARCH METHOD}

This research uses qualitative research. At this level, qualitative research includes an interpretive approach. This means that qualitative researchers study matters in their natural setting, trying to understand, or interpret phenomena in terms of the meaning that people bring into them (Denzin \& Lincoln, 2011). Furthermore, this research uses an approach. This research uses a case study approach with an exploratory study in which Kotler and Lane (2006) explain exploratory or exploratory, which is one research approach used to examine something (which attracts attention) that is not yet known, not yet understood or not yet recognized well. In order to obtain the expected results in this study, researchers conducted data collection by interview method directly on 20 informants in the Banyuwangi Government and observation. The activity which is also the object of research is to understand the main tasks and functions of each researcher in order to obtain maximum results. The purpose of the researchers is only to convey the clearest, most comprehensible and comprehensible results which are then outlined in this article. Researchers are required to understand in terms of motives, social, individual life experiences and behavior of respondents. Then the steps taken by researchers to analyze interview data by: (a) informal conversation interviews, (b) approaches using interview general guidelines, and (c) open standard interviews. The results of the interviews were recorded with a recording aid and then processed with NVIVO software then analyzed and the conclusions drawn from the interviews.

\section{A. Result}

\section{RESULT AND DICUSSION}

Risk assessment is basically an activity to identify events that threaten the achievement of the goals and objectives of Government Agencies. This conception requires a pre-condition so that the process of risk identification and analysis can be carried out efficiently and effectively according to characteristics. Risk Assessment according to Government Regulation Number 60 of 2008, namely the existence of the SPIP implementation design. Initial data on SPIP weaknesses should be analyzed. Further explained in Article 13 (1) Leaders of Government Agencies are required to conduct a risk assessment. (2) Risk assessment as referred to in paragraph (1) consists of: a. Identification of risk; and b. risk analysis. (3) In the context of risk assessment as referred to in paragraph (1), the leadership of the Government Agency determines: The objectives of Government Agencies; and Objectives at the activity level, based on the laws and regulations.

Elucidation of Article 16 concerning risk identification as referred to in Article 13 paragraph (2) letter a shall be carried out at least by:

a) use methodologies that are appropriate for the objectives of Government Agencies and objectives at the activity level comprehensively;

b) use adequate mechanisms to recognize risks from external and internal factors;

c) Assess other factors that can increase risk.

Added to the explanation in Article 17 (1) Risk analysis as referred to in Article 13 paragraph (2) letter $b$ is carried out to determine the impact of the risks that have been identified on achieving the objectives of Government Agencies. (2) The Leaders of Government Agencies apply the precautionary principle in determining the acceptable level of risk. Thus the Leaders in each Government Agency must carry out risk control activities that are appropriate to the size, complexity, and nature of the tasks and functions of each Government Agency 
concerned. The expectation of risk management is to minimize the occurrence of significant losses if it is not immediately repaired from the beginning.

Begin from a good risk management is needed a good culture is like risk culture. A high level of risk culture maturity in an organization provides it with a means to manage risks more effectively, ultimately guiding the way in which management, employees and business units take risks. Effective tone-at-the-top and risk communication have been highlighted as key elements required for a mature risk culture (Gandz \& Seijts, 2013). Boultwood and Dominus (2014) indicated that developing a mature risk culture requires continuous and sustainable commitment from the highest level in the organization.

As a response to the importance of being aware of the risks that could occur, the Regent of Banyuwangi issued a Draft Regulation to overcome the obstacles that occur including low understanding about risk, not entrenched considering risks, local culture is different and has not been standardized in the identification and application. This effort is made to the right way and quickly cultivate risk awareness, effective control tools, to prevent / control risk, commitment from all levels of management, commitment from all levels of management and integration of risk management in the process of each work activity. To achieve this requires joint commitment from the leader level to employees, a good culture that starts from good habits or behaviors, the same tastes to achieve organizational goals, high tolerance for differences, good governance and good policies right. It can make a good governance in local government because of good governance provides strong leadership qualities and enhances reliable judgment which ensures that an organization's resources are used in the most effective way to assist the people and causes its set up for benefit (Driscoll, 2011).

An organization's orientation toward people interactions and coordination will fall on a spectrum from highly independent to highly interdependent. Cultures that lean toward the former place greater value on autonomy, individual action, and competition. Those that lean toward the latter emphasize integration, managing relationships, and coordinating group effort. People in such cultures tend to collaborate and to see success through the lens of the group (B. Lee, \& Cheng, 2018). As organizations like Banyuwangi Government's goal in making risk management policies is to create and develop a culture of strategic and operational decisions through careful and careful consideration by utilizing good risk management processes. In creating awareness of the importance of risk management it is necessary to conduct extensive outreach and training to all employees of risk stakeholders, so that they become aware of and aware of the importance of risk management in carrying out their duties and in decision making. Alignment with intensive and sanctions, meaning that organizations need to align the achievement of desired goals, through efforts to provide incentives and sanctions.

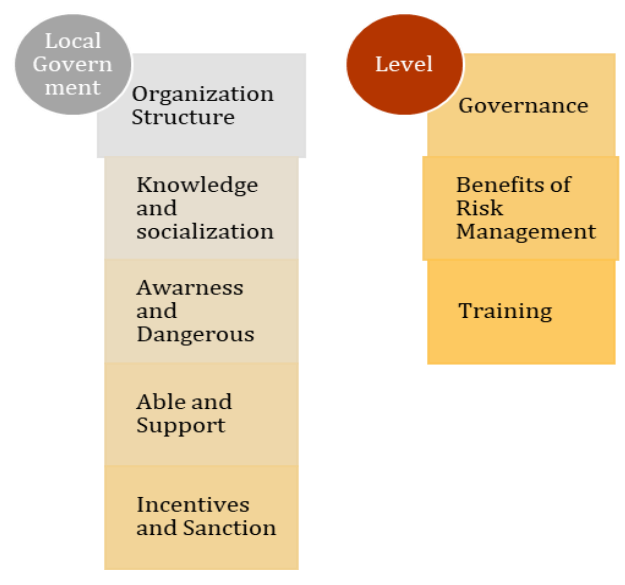

Figure 1

Local Government and Level

Source: Interview (2019) 
Local Government focus in a risk management is expected to make the organization aware of risk and be careful in decision making. The expected outcome of such behavior is the optimal decision. The decision is better than the decision taken without taking into account the risk.

\section{B. Discussion}

The most important thing for managing risk management according to ISO 31000 starts with creating value, an integral part of the organizational process, part of decision making, explicitly discussing uncertainty, systematically structured and timely, based on the best available information, specifically designed, paying attention to human and cultural factors, transparent and inclusive, dynamic, repetitive and sensitive to change, and facilitating continuous improvement and organizational progress.

Local Government of Banyuwangi proactively ensures that the implementation of risk management culture can run well by ensuring continuity, community service, and goals or objectives according to the vision and mission of the Regional Head can be realized. To realize this it requires synergy and commitment at every level of employees and Government Management needs to continually recognize risks in organizational governance which can affect the ability to achieve the goals set by the right decision. Decision making will also have an impact on reward or punishment depending on how well management can manage risk. Government of Banyuwangi has committed that those who can manage high risk become low or whose jobs have high risk and then the employee cares to be able to minimize the risk then the Additional Employee Income as an award but if the employee is not concerned and is not aware of the risk which has the potential to even infringe, punishment can also be obtained. This was also started by the Banyuwangi Government in building a culture of risk awareness as a representative of the local government as follows:

Table 1

Risk Management Culture

\begin{tabular}{|c|c|c|c|}
\hline \multicolumn{4}{|c|}{ Local Government Risk Management Culture Maps } \\
\hline Role of Leader & Good Governance & Human Resource & Decision Making \\
\hline $\begin{array}{l}\text { Commitment to } \\
\text { integrity and ethical } \\
\text { value who create by the } \\
\text { leader }\end{array}$ & $\begin{array}{l}\text { Routine inspections and } \\
\text { clear objectives } \\
\text { specified }\end{array}$ & $\begin{array}{l}\text { Attract, develop and } \\
\text { retain competent people }\end{array}$ & $\begin{array}{l}\text { Ongoing and/or } \\
\text { separate evaluations } \\
\text { conducted }\end{array}$ \\
\hline $\begin{array}{l}\text { Synergy between } \\
\text { structures, authorities, } \\
\text { and responsibility }\end{array}$ & $\begin{array}{l}\text { Control activities } \\
\text { selected and developed, } \\
\text { control deployed } \\
\text { through policies and } \\
\text { procedures }\end{array}$ & $\begin{array}{l}\text { People held accountable } \\
\text { for internal control }\end{array}$ & $\begin{array}{l}\text { Internal Control } \\
\text { deficiencies evaluated } \\
\text { and communicated }\end{array}$ \\
\hline $\begin{array}{l}\text { Independent board of } \\
\text { directors oversight }\end{array}$ & $\begin{array}{l}\text { General IT control or } \\
\text { online transparency } \\
\text { Report Daily, Quality } \\
\text { Information obtained, } \\
\text { generated and used }\end{array}$ & $\begin{array}{l}\text { Create a good work } \\
\text { culture } \\
\text { Motivation }\end{array}$ & $\begin{array}{l}\text { Risk-Based Decision } \\
\text { Making } \\
\text { Punishment and } \\
\text { Rewards }\end{array}$ \\
\hline
\end{tabular}

Source: Data of Interview from NVIVO software (2019)

Mapping the risks above will certainly provide benefits that are able to provide adequate confidence to the Supervisory Board, Managerial including the Regional Head, reduce the risk of failure that occurs in the operational activities of each Government entity, the culture of risk awareness can lead to the habit of managing risk well by doing risk identification from the beginning, able to increase the effectiveness of capital utilization and in the future be able to create new opportunities. Risk management is also very important is needed and implemented as part of preventive action against existing risks and the likelihood of events that can occur. 


\section{CONCLUSION}

The most important thing for managing risk management according to ISO 31000 starts can be applied with creating value, an integral part of the organizational process, part of decision making, explicitly discussing uncertainty, systematically structured and timely, based on the best available information, specifically designed, paying attention to human and cultural factors, transparent and inclusive, dynamic, repetitive and sensitive to change, and facilitating continuous improvement and organizational progress. The implementation of a culture of risk must be understood from the start. Risk management is designed to identify potential events that, if they occur, will affect the entity; and managing risk in risk appetite and risk tolerance include at Local Government.

Limitation of this research is that it only presents one region that is used as a portrait to illustrate the creation of a risk-conscious culture, namely Banyuwangi caused by this Government has implemented risk management culture in this office. It is hoped that further research will be able to be applied by other Local Governments so that risk management is more resolved and provides better information and appropriate risk management.

Mitigating risks in every activity is really needed starting with the awareness of each individual in order to achieve the goals, vision and mission of the Regional Government, namely to become a Government that is more able to realize transparent, accountable governance and provide public welfare.

\section{ACKNOWLEDGEMENT}

Author would like to express my special thanks of gratitude to Governance and Public Sector (GPS) as my research group and University of Jember as well as our institution who gave me the golden opportunity to do this wonderful project on the topic Risk Management Culture, which also helped me in doing a lot of Research and i came to know about so many new things Author am really thankful to them. Secondly i would also like to thank my parents and friends who helped me a lot in finalizing this project within the limited time frame.

\section{REFERENCE}

Bird, L., Mahr, W., \& Milde, T. (2018). Good Practice Guidelines 2013.

Boultwood, B., \& Dominus, M. (2014). Developing an effective risk culture. Electric Perspectives, 39(3), 57-60.

Cortez, A. (2011). Winning at risk: Strategies to go beyond Basel. New York: John Wiley and Sons

Denzin, N. K., \& Lincoln, Y. S. (Eds.). 2011. The SAGE handbook of qualitative research. Sage. London

Driscoll, L. 2011. Time of evoluktion [Governance of voluntary and community organization]. Keeping Good Companies, 63 (7), 407-409.

Gandz, J., \& Seijts, G. (2013). Leadership and Risk Culture. Ivey Business Journal Online, Mar/Apr.

Groysberg, B., Lee, J., Price, J., \& Cheng, J. (2018). The leader's guide to corporate culture. Harvard Business Review, 96(1), 44-52.

Government Regulation Number 60 Year 2008 concerning Government Internal Control System

Haviernikova, K. (2016). The Identification and Classification Of Risks In Terms Of Cluster Cooperation. In Proceedings of 1st International Conference Contemporary Issues in Theory and Practice of Management (ed. M. Okręglicka, I. Gorzeń-Mitka, A. LemańskaMajdzik, M. Sipa, A. Skibiński), Czestochowa University of Technology, pp. 130-136)

Mamduh, M.Hanafi. (2016). Manajemen Risiko. Yogyakarta: UPP STIM YKPN

Kotler, P., \& Keller, K. L. (2006). Marketing Management: Pearson Education. Ltd. New Jersey.

Sheedy, E., \& Griffin, B. (2018). Risk governance, structures, culture, and behavior: A view from the inside. Corporate Governance: An International Review, 26(1), 4-22.

The Institute of Risk Management. (2010). A Structured Approach To enterprise Risk Management (ERM) And The Requirement of ISO 31000.

Tiwari, A., \& Jauhar, V. (2017). Risk Management and Internal Audit Effectiveness in chievement of the Local Government Developments. 